\title{
Ю.В. Смородина
}

\section{"МЯГКАЯ СИАА" РОССИИ \\ И ПУТИ ПОВЫШЕНИЯ ЕЕ ЭФФЕКТИВНОСТИ}

Аннотация. В сообщении идет речь о концепции «мягкой силь»» России и путях реализации этой концепции. Рассматриваются внутриполитические и внешнеполитические методы, с помощью которых Россия может эффективнее использовать «мягкую силу».

Ключевые слова: «мягкая сила», «жесткая сила», внутренняя политика, внешняя политика, национальные интересы.

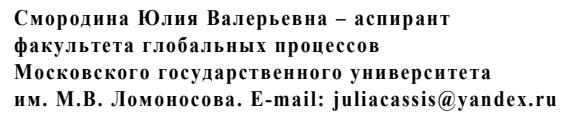

Yu.V. Smorodina. Russian «Soft Power» and Ways to Improve its Efficiency

Abstract. The article studies the concept of Russian «soft power», the ways of its implementation, domestic and foreign political methods of effective use of the "soft power» by Russia.

Keywords: «soft power», «hard power», domestic policy, foreign policy, national interests.

Smorodina Yulia Valirievna - Ph.D. student of the Faculty

of Global Studies of Lomonosov Moscow State University.

E-mail: juliacassis@yandex.ru

На рубеже XX-XXI вв. мир оказался на пороге новой эпохи. Процессы социального развития глобальны по своей природе, поэтому происходит переход к глобальному информационному обществу, формируются транснациональные информационные структуры. В современной мировой политике заметно возрастает влияние «мягких» инструментов воздействия на систему 
международных отношений. Использование жестких, силовых методов становится всё менее эффективно и более опасно.

В меняющейся международной системе отношений успех страны определяется сегодня не только экономическими факторами, военной мощью или наличием природных ресурсов. Большая часть этого успеха зависит от наличия или отсутствия у страны «мягкой силы». «Мягкая сила» - это сочетание нескольких факторов: привлекательной для внешнего мира модели социально-экономического развития, культуры, политической системы и ценностных ориентаций. Большое значение имеет положительная и конструктивная деятельность, выходящая за пределы одного государства, помощь в разрешении конфликтов.

В последнее время в России развернулась широкая дискуссия о необходимости более широкого использования «мягкой силы» для достижения своих национальных интересов. Сегодня практически любое событие в мировой политике не происходит без использования «мягкой силы», многократно усиленной с помощью информационных и когнитивных технологий.

В течение почти столетия существования роль Советского Союза и России в качестве его преемницы на мировой политической арене постоянно менялась. Максимальное влияние СССР было достигнуто в 1945-1961 гг., после чего последовало снижение, особенно после 1968 г. [15]. Времена холодной войны характеризовались не только военно-политическим противостоянием двух сверхдержав - СССР и США, но и борьбой двух идеологий. Фактически идеологическое противостояние было борьбой «мягкой силы» двух стран. И у СССР, и у США были свои союзники, с помощью которых идеологии, условно говоря, «коммунизма» и «капитализма» транслировались остальному миру. После распада СССР Россия лишилась своей идеологии, общей системы ценностей и, как следствие, «мягкой силы» [2].

«Мягкая сила» Запада существенно способствует усилению таких информационных потоков, которые подогревают сепаратистские настроения в различных регионах Российской Федерации и ослабляют единство нации, ее национальную культуру. Политика «мягкой силы», дополненная новейшими технологиями, позволяет эффективно работать с сознанием людей, изменять историческую память, формировать новую систему ценностей, выгодную для проводящих эту политику элит. Тем не менее это может происходить только при отсутствии сколько-нибудь серьезного противодействия.

В этой ситуации есть только одно решение - разрабатывать собственную концепцию «мягкой силы».

Сегодняшняя Россия активно восстанавливает свое влияние в мире, однако делается это прежде всего с помощью «жесткой силы». Это вполне объяснимо: «Мягкая сила» - эффективное подспорье для других видов международных политических инструментов, но она не является их полной заменой. 


\section{РАЗМЫШЛЕНИЯ, СООБЩЕНИЯ, КОММЕНТАРИИ}

Очевидно, что «мягкая сила» России не может опираться на ту же систему ценностей, на которую опирается «мягкая сила» западных стран, поскольку в этом случае Россия фактически попадет под идеологическую зависимость от США и Европы. Основой новой российской идеологии могут стать ценности мирного сосуществования народов: «Для реализации "мягкой силы” России необходимо создавать свою логическую связку, которая бы отвечала имиджу и миссии России в сложном многополярном мире. Это может быть логическая связка: Россия - гарантия безопасности. Миссия России невзирая на лишения и нужды своего народа, не жалея сил и затрат, гарантировать безопасность и стабильность в регионе, на континенте и в глобальном мире в целом» $[1$, с. 18$]$.

Необходимо сформировать образ России как страны, где бережно сохраняются богатые исторические традиции русской культуры, где уважаются культуры всех народов, где существует творческая свобода и плюрализм. Образ России должен быть образом страны, где интересы федерального центра и регионов согласуются - при уважении суверенитета и государственной целостности Российской Федерации. Позиционирование России как динамично развивающейся страны, члена БРИКС и ведущего государства Шанхайской организации сотрудничества, несомненно, усилит привлекательность ее «мягкой силы» [1].

Приоритетом политики «мягкой силы» должно стать предоставление систематической и всесторонней поддержки соотечественникам за рубежом, защита постоянно проживающих за границей российских граждан, помощь в реализации прав русскоязычного населения в иностранных государствах.

Улучшению имиджа России, конечно, будет служить улучшение условий жизни граждан страны, создание эффективной системы образования, расширение гражданских прав и свобод. Можно сделать вывод, что «мягкая сила» России не будет эффективна без проведения грамотной внутренней политики.

\section{Библиография}

1. Леонова О.Г. Мягкая сила: Инструменты и коэффициенты влияния // Обозреватель Observer. 2014. № 3. С. 18-28.

2. Паршин П. Проблематика «мягкой силы» во внешней политике России // Аналитические доклады. М.: МГИМО-Университет, 2013. Вып. 1 (36). Март. 37 с.

\section{References}

Leonova O.G. Mjagkaja sila: Instrumenty i kojefficienty vlijanija // Obozrevatel' - Observer. 2014. N 3. P. 18-28.

Parshin P. Problematika «mjagkoj sily» vo vneshnej politike Rossii // Analiticheskie doklady. M.: MGIMO-Universitet, 2013. Vyp. 1 (36). Mart. 37 p. 